\title{
The distribution of phosphorus from recycled fertilizers to different soil fractions determines the phosphorus availability in soil
}

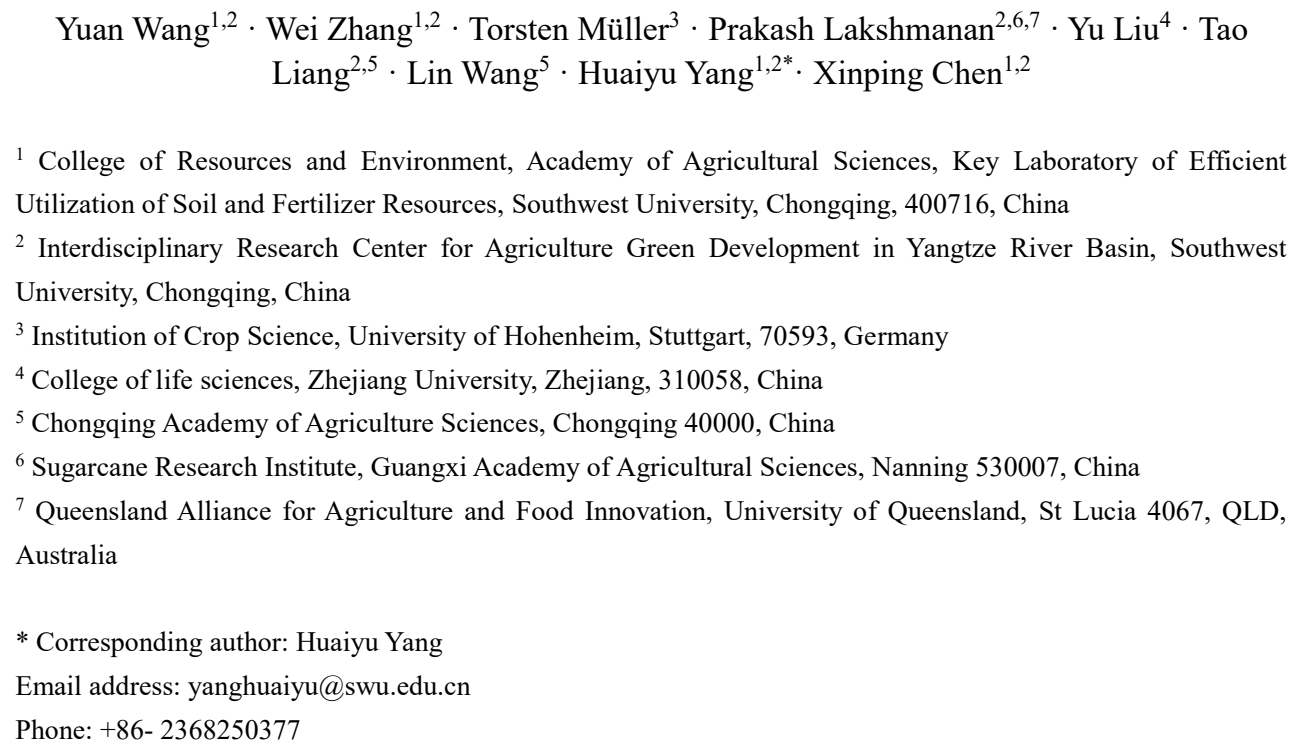

\section{Abstract}

Recycling of agricultural wastes to reduce mineral fertilizer input, in particular phosphorous $(\mathrm{P})$, plays crucial role in sustainable agriculture production. Understanding the transformation of phosphorous $(\mathrm{P})$ fractions and their bioavailability following soil application of different renewable P-contained fertilizers is very important for improving P use efficiency and reducing environmental risks. In this study, the effects of mineral P-fertilizer superphosphate and recycled P-fertilizers, i.e., poultry manure, cattle manure, maize straw and cattle bone meal, on their distribution to different soil $\mathrm{P}$ fractions, their transformation and the availability of soil $\mathrm{P}$ were determined by soil $\mathrm{P}$ sequential fractionation and ${ }^{31} \mathrm{P}$ solution nuclear magnetic resonance (NMR). The results showed that addition of mineral $\mathrm{P}$ fertilizer, poultry manure and cattle manure increased $\mathrm{P}$ fixation in a red soil more than that in a fluvo-aquic soil. In both fluvo-aquic and red soils, cattle manure out-performed all other recycled P sources used in improving soil $\mathrm{P}$ availability. The concentration of Olsen-P in fluvo-aquic and red soils supplemented with cattle manure were increased by $41 \%-380 \%$ and $16 \%-70 \%$ than the other recycled P sources. A structural equation model (SEM) explained $95 \%$ and $91 \%$ of Olsen-P variation in fluvo-aquic and red soils, respectively. Labile P fractions had positive effects on Olsen-P of fluvo-aquic and red soils. ${ }^{31} \mathrm{P}-\mathrm{NMR}$ study 
showed that amount of orthophosphate was the main factor affecting the availability of $\mathrm{P}$ from different $\mathrm{P}$ sources. In summary, cattle manure was found to be a superior renewable source of $\mathrm{P}$ in improving bioavailable $\mathrm{P}$ in soil, and its use thus has considerable practical significance in P recycling.

Keywords: phosphorus source; soil $\mathrm{pH}$; P sequential fractionation; ${ }^{31} \mathrm{P}-\mathrm{NMR}$

\section{Introduction}

Sufficient supply of plant available phosphorus (P) in soil is critical for optimal growth and high yields of crops (Haslam et al., 2019; Zhang et al., 2019). Application of P fertilizer is an important measure to supplement soil P in most agricultural regions. However, excessive application of P fertilizer is common (Withers, 2019; Campbell et al., 2017; Kalkhajeh et al., 2021) and it causes accumulation of $\mathrm{P}$ in soil and the attendant environmental and crop quality issues (Cui et al., 2021; Liu et al., 2016; Lucas et al., 2021). Recovering and recycling $\mathrm{P}$ in agricultural wastes such as manure, straw, animal bone meal, etc. could reduce P inputs globally (Qaswar et al., 2020; Guan et al., 2020; Ylivainio et al., 2008; Kaikake et al., 2009; Mortola et al., 2019). To this end, understanding the transformation of soil $\mathrm{P}$ fractions and its bioavailability following agricultural waste recycling is particularly important for improving crop $\mathrm{P}$ utilization, $\mathrm{P}$ fertilizer management and reducing environmental risks.

A series of physico-chemical transformations (dissolution, precipitation, adsorption and desorption) occurs when P-containing recycled fertilizers are applied to the soil, which are regulated by soil $\mathrm{pH}$, organic matter content and soil biology (Yuan et al., 2021; Lemming et al., 2020). The addition of mineral P (superphosphate, SSP) leads to an initial spike in $\mathrm{P}$ availability, followed by $\mathrm{P}$ adsorption and precipitation occurring over time, and culminating in decreased $\mathrm{P}$ availability in soil (Tiessen and Moir, 1993). Compared with mineral P, organic inputs are beneficial to the conversion of moderately labile inorganic P to available P (Chen et al., 2021). Organic fertilizers contain a variety of P compounds, including a large proportion of orthophosphate (Lin et al., 2015; Liang et al., 2017). It also affect soil P dynamics by changing its P adsorption capacity (Gatiboni et al., 2019; Barnett, 1994). The concentrations of labile and moderately labile $\mathrm{P}$ fractions in soil were significantly increased after applying organic fertilizer for four consecutive years (Negassa and Leinweber, 2009). Compared with mineral P, cattle manure application increases the content of moderately labile P, microbial biomass and microbial activity of soil, which facilitate the provision of plant available P for a longer period (Braos et al., 2020; Neufeld et al., 2017; Zhang et al., 2018). Also, soil application of organic fertilizer was found to increase the proportion of labile organic phosphate (Po) and inositol hexaphosphate (IHP), and decrease stable Ca-P content (Yan et al., 2018). Due to the 
compositional variation in animal feed and the characteristics of digestive system, different livestock manures are likely to have different effects on P distribution in soil (Garcia-Albacete et al., 2012; Freiberg et al., 2020). For instance, $87 \%$ of $\mathrm{P}$ in cattle manure was water-soluble, while it was just $69 \%$ in poultry manure (Li et al., 2014 ; Pagliari and Laboski, 2013). The fractions of P from different P-containing fertilizers, and their effects on soil P availability are very complex. Thus, it is necessary to identify and quantify $\mathrm{P}$ fractions from different $\mathrm{P}$ sources and their distribution in soil P fraction to determine the potential bioavailability and the environmental impact of P from various sources.

The relative contents of inorganic and organic $\mathrm{P}$ in soil is greatly influenced by soil type, land use and the type of organic amendment applied (Zhang et al., 2020; Borno et al., 2018; Pizzeghello et al., 2011). A comparative study of $\mathrm{P}$ fractions in a typical red soil (low $\mathrm{pH}$ ) and a fluvo-aquic soil (slightly alkaline $\mathrm{pH}$ ) will help reveal their transformation mechanism and relationship with edaphic condition. The improved Hedley fractionation divides soil $\mathrm{P}$ fractions into labile $\mathrm{P}$, moderately labile $\mathrm{P}$, sparingly labile $\mathrm{P}$ and non-labile $\mathrm{P}$ fractions (Negassa and Leinweber, 2009; Tiessen et al., 1984). This approach is widely used to study transformation of P fractions (Zhang et al., 2021). However, information on soil $\mathrm{P}$ transformation following organic fertilizer application remains limited. A previous study reported no change in soil organic P fractions following application of organic fertilizers for 62 consecutive years, while another study found an opposite trend of increased contents of soil organic and inorganic P fractions with long-term application of organic fertilizers (Annaheim et al., 2015; Lu et al., 2020).

Although soil P sequential fractionation defines soil P fractions according to the solubility of $\mathrm{P}$ component in the extract, it provides only limited information on the biogeochemical processes and plant availability of P. Hence ${ }^{31} \mathrm{P}$ solution nuclear magnetic resonance (NMR) has been widely used to study soil P transformation, which affords more opportunities for a better understanding of organic P species. For example, Wang et al. (2019) used ${ }^{31}$ P-NMR to characterize the transformation of organic $\mathrm{P}$ compounds during the formation of organic soils in an alpine forest in Bavaria over 1500 years (Wang et al., 2019). And, it was also used to explore the source, translocation and transformation of P reservoir in agricultural soil, and to further understand the accumulation of residual P in soil (Joshi et al., 2018). The combination of the classical P sequential fractionation methodology and the advanced $\mathrm{P}$ speciation analysis methodology allows a more powerful approach to study $\mathrm{P}$ turnover in soil and related substances.

Recycling P, nitrogen and other elements from organic waste is an important and necessary step for a green and sustainable agriculture and clean environment (Liu et al., 2020b; Almeida et al., 2019; Powers et al., 2019; Withers, 2019; Zaccheo et al., 1997). Fluvo-aquic and red soils are found extensively in agricultural lands of China. 
Compared with fluvo-aquic soil, red soil readily adsorbs $\mathrm{P}$ and reduces its bioavailability, necessitating high $\mathrm{P}$ fertilizer use in agriculture. However, little is known about soil $\mathrm{P}$ dynamics in red soils from a fertilizer management perspective, especially in relation to organic fertilizer use. The research reported here is part of our effort to reduce mineral $\mathrm{P}$ fertilizer consumption by replacing it with manure, and to facilitate maximum recycling of P for food production and environmental sustainability. In this study we (1) evaluated the impact of applying different $\mathrm{P}$ fertilizers, including organic fertilizers, on soil $\mathrm{P}$ composition in fluvo-aquic and red soils, and (2) studied the relationship between various soil $\mathrm{P}$ fractions and available $\mathrm{P}$ concentration, and how it is affected by various types (mineral and organic) of $\mathrm{P}$ fertilizers.

\section{Materials and methods}

\subsection{Experimental material and characteristics}

The experiment was carried out in a plant growth chamber located in the Department of Plant Nutrition, College of Resources and Environment, Southwest University, Chongqing, China. Soil samples were collected from calcareous fluvo-aquic soil in Quzhou, Hebei Province and red soil in Shilin County, Yunnan Province in June 2020. The fluvo-aquic soil properties were: $8.8 \mathrm{mg} \cdot \mathrm{kg}^{-1}$ Olsen-P, $914.7 \mathrm{mg} \cdot \mathrm{kg}^{-1}$ total $\mathrm{P}, \mathrm{pH} 7.9$ (water: soil ratio 2.5: 1), $13.2 \mathrm{~g} \cdot \mathrm{kg}^{-1}$ organic matter, $1.9 \mathrm{mg} \cdot \mathrm{kg}^{-1} \mathrm{NH}_{4}{ }^{+}-\mathrm{N}, 24.3 \mathrm{mg} \cdot \mathrm{kg}^{-1} \mathrm{NO}_{3}{ }^{-}-\mathrm{N}$, and $26.1 \mathrm{mg} \cdot \mathrm{kg}^{-1}$ exchangeable potassium. The properties of red soil were: $28.2 \mathrm{mg} \cdot \mathrm{kg}^{-1}$ Olsen-P, $1083.7 \mathrm{mg} \cdot \mathrm{kg}^{-1}$ total $\mathrm{P}, \mathrm{pH} 5.7$ (water: soil ratio 2.5: 1), $34.9 \mathrm{~g} \cdot \mathrm{kg}^{-1}$ organic matter, $2.4 \mathrm{mg} \cdot \mathrm{kg}^{-1} \mathrm{NH}_{4}{ }^{+}-\mathrm{N}, 42.7 \mathrm{mg} \cdot \mathrm{kg}^{-1} \mathrm{NO}_{3}{ }^{-}-\mathrm{N}$, and $78.2 \mathrm{mg} \cdot \mathrm{kg}^{-1}$ exchangeable potassium. Before the experiment, both soils were dried and sieved $(2 \mathrm{~mm})$, then re-moistened, and pre-incubated in the dark at $25^{\circ} \mathrm{C}$ for $7 \mathrm{~d}$, with $30 \%$ WHC.

Five P sources including single superphosphate, poultry manure, cattle manure, maize straw and cattle bone powder were used in the experiment. The total N-P-K contents of poultry manure, cattle manure, maize straw and cattle bone powder were 16-20-32 $\mathrm{g} \cdot \mathrm{kg}^{-1}, 7-5-12 \mathrm{~g} \cdot \mathrm{kg}^{-1}, 7-5-8 \mathrm{~g} \cdot \mathrm{kg}^{-1}, 37-93-1 \mathrm{~g} \cdot \mathrm{kg}^{-1}$, respectively.

\subsection{Experiment design}

The experiment was set up with fluvo-aquic and red soils, each with five different P sources and a control. The treatments were mineral P (single superphosphate, SSP), poultry manure (PM), cattle manure $(\mathrm{CM})$, maize straw (MS), cattle bone meal (CB) and without P (CK). The air-dried soil and different recycled organic fertilizers were sieved with $2 \mathrm{~mm}$ stainless steel sieve, and the soil was mixed with fertilizers to supply $120 \mathrm{mg}$ total P per $\mathrm{kg}$ soil. The total amount of $\mathrm{N}\left(\mathrm{Ca}\left(\mathrm{NO}_{3}\right)_{2} \cdot 4 \mathrm{H}_{2} \mathrm{O}\right)$ and $\mathrm{K}(\mathrm{KCl}), 200$ and $325 \mathrm{mg} \cdot \mathrm{kg}^{-1}$ of soil, respectively, was normalized for all treatments. The specific amount of fertilizer for each treatment is shown in Table 1. In all treatments, an experimental unit (a replicate) constitutes $100 \mathrm{~g}$ of soil enriched with an inorganic or organic 
fertilizer, or with no P fertilizer for control, sampled into a $200 \mathrm{ml}$ plastic bottle. All replicates were kept at $25^{\circ} \mathrm{C}$ in an incubator for 70 days. The soil moisture content (MC) was maintained at $30 \%$ throughout the experiment by weighing. A total of 432 experimental units ( 2 soil types $\times 6$ treatments $\times 36$ repetitions) were used in this experiment. Large number of replicates allowed destructive sampling on each sampling date. Soil samples were taken for Olsen-P analysis at $0,3,7,14,21,28,35,42$ and 70 days after adding the fertilizer. We analyzed the $\mathrm{P}$ fractions of day 70 soil samples.

\subsection{Sample analysis}

Olsen-P was determined by phosphomolybdate method using soil extract prepared with $0.5 \mathrm{~mol} \cdot \mathrm{L}^{-1} \mathrm{NaHCO}_{3}$, pH $8.5\left(180 \mathrm{RPM}, 25^{\circ} \mathrm{C}\right)$ and 1:20 soil (W/V) (Olsen, 1954). After acid digestion with ammonium paramolybdatevanadate reagent, total phosphorus was determined by colorimetry (Olsen and Sommers, 1982, Koenig and Johnson, 1942). Soil total organic carbon content was determined following a wet oxidation method with $\mathrm{K}_{2} \mathrm{Cr}_{2} \mathrm{O}_{7}$ and concentrated $\mathrm{H}_{2} \mathrm{SO}_{4}$ (Schumacher, 2002). The sequential extraction procedure proposed by Tiessen and Moir (1993) was used to obtain different soil P fractions: Resin-P, $\mathrm{NaHCO}_{3}-\mathrm{P}, \mathrm{NaOH}-\mathrm{P}, \mathrm{HCl}-\mathrm{P}$ and Residual P. Organic $\mathrm{P}(\mathrm{Po})$ in different extracts $\left(\mathrm{NaHCO}_{3}-\mathrm{P}, \mathrm{NaOH}-\mathrm{P}\right.$, conc.HCl-P) was determined by ammonium persulfate digestion method (Tiessen and Moir, 1993). Phosphorous content of extracts was quantified colorimetrically (Shen et al., 2011). The concentration of Po was calculated as the difference between total P and inorganic P. Fig. S1 shows the detailed analysis process.

\section{Quantitation of soil P species variation by ${ }^{31} \mathrm{P}-\mathrm{NMR}$ assay}

Po analysis was also performed by NaOH-EDTA extraction followed by ${ }^{31} \mathrm{P}-\mathrm{NMR}$ analysis (Xu et al., 2012; Li et al., 2015). For the ${ }^{31} \mathrm{P}-\mathrm{NMR}$ analysis, soil samples at the end of 70-day incubation were ground into powder and sieved through a $100-\mu \mathrm{m}$ mesh. They were then extracted with a solution of $0.25 \mathrm{~mol} \cdot \mathrm{L}^{-1} \mathrm{NaOH}$ and 0.05 $\mathrm{mol} \cdot \mathrm{L}^{-1}$ EDTA for $16 \mathrm{~h}$ at room temperature at a sediment and extract ratio of 1:10 (Shafqat et al., 2009; Li et al., 2017). Adjust the solution $\mathrm{pH}$ to $9.0 \pm 1.0$, stable for 30 minutes, centrifuged at $12000 \mathrm{~g}\left(20^{\circ} \mathrm{C}\right)$ for 30 minutes. The NaOH-EDTA solution was frozen and lyophilized for ${ }^{31} \mathrm{P}-\mathrm{NMR}$ analysis. This extract was then re-dissolved in 2 $\mathrm{mL}$ of $1 \mathrm{~mol} \cdot \mathrm{L}^{-1} \mathrm{NaOH}$ solution for $2 \mathrm{~h}$ by vortex shaking, and the suspension centrifuged at $12,000 \mathrm{~g}\left(20^{\circ} \mathrm{C}\right)$ for $30 \mathrm{~min}$ (Ding et al., 2010). An aliquot $(940 \mu \mathrm{L})$ of the supernatant was transferred into 5-mm NMR tube, and added with a deuterated aqueous solution of methylenebisphosphonic acid-P, $\mathrm{P}^{\prime}$-disodium salt (MDP, Epsilon Chimie, Brest) as internal standard $(\delta=16.62 \mathrm{ppm})$, to reach a final $2.65 \mathrm{mM}$ concentration. Three replicate pots for each treatment were prepared for NMR analyses (Li et al., 2017).

Solution ${ }^{31} \mathrm{P}-\mathrm{NMR}$ spectra were obtained using a Bruker $600-\mathrm{MHz}$ spectrometer (Bruker, AVANCE III, 
Switzerland) operated at $242.93 \mathrm{MHz}$ at a temperature of $25^{\circ} \mathrm{C}$. A power-gated decoupling pulse, a relaxation delay of $2 \mathrm{~s}$, an acquisition time of $0.67 \mathrm{~s}$ and 4000 scans was applied in the measurement. Chemical shifts were recorded relative to an $85 \% \mathrm{H}_{3} \mathrm{PO}_{4}$ standard $(\delta=0 \mathrm{ppm})$. All ${ }^{31} \mathrm{P}$ spectra were baseline corrected and processed by MestReC software (v. 4.9.9.9). Signal areas were calculated by integrating the individual peaks resulting from a deconvolution process. The MDP internal standard was contained in the solution used to dissolve samples for NMR analyses and served also to calibrate the frequency axis, standardize data and perform a quantitative assessment of P forms. Signals were assigned to P compounds based on data in the literature (Cade-Menun, 2005; Turner, 2008; Cade-Menun and Liu, 2014; Mclaren et al., 2020; Hill and Cade-Menun, 2009). The solution ${ }^{31} \mathrm{P}$ NMR spectra of NaOH-EDTA extracts reflected the different P sources in Fig. S2.

\subsection{Statistical analysis}

NMR data were processed using the MestReNova package (V8.1.4 Mestrelab Research, Spain). All experimental data were analyzed by one-way analysis of variance (ANOVAs) with SPSS 13.0 (SPSS Inc., Chicago, IL, USA) software. When ANOVAs were significant, treatment means for independent variables were compared using Fisher's LSD Tests. All significance levels were set to $P<0.05$. The structural equation model (SEM) was used to identify the potential driving factors of transformation of different $\mathrm{P}$ fractions following different fertilizer application in the two experimental soils using IBM SPSS AMOS 22.0 (IBM Corporation 2013). Root-mean square-error of approximation (RMSEA) $(<0.08)$, chi-square $\left(\chi^{2}\right)\left(\chi^{2} / \mathrm{df}<2\right)$, and the $P$ value of $\chi^{2}(\mathrm{P}>0.05)$ were used to evaluate the model fitting.

\section{Results}

\subsection{Cattle manure was far superior than other common organic sources to increase soil Olsen-P}

In both soils, the Olsen-P fluctuated with incubation time (Fig. 1). Based on the effect size, treatments could be grouped into (1) those that strongly improved Olsen-P and (2) those slightly or not improved Olsen-P, following soil enrichment with different P sources. The highest concentration of Olsen-P was found in SSP treatment (Fig. 1). During 0-70 days of incubation, the Olsen-P concentration of SSP, PM and CM enriched fluvo-aquic soil has increased by $538 \%, 236 \%$ and $374 \%$ compared with CK in average, respectively. In SSP, PM, and CM enriched red soil, the Olsen-P concentration was increased by $80 \%, 41 \%$ and $63 \%$ compared with CK in average during 0-70 days of incubation, respectively. Among the organic P sources used, cattle manure outperformed other sources in improving soil Olsen-P. In both fluvo-aquic and red soil, the Olsen-P content of soil supplemented with cattle manure was increased respectively by $41 \%$ to $380 \%(\mathrm{p}<0.05)$ and $16 \%$ to $70 \%(\mathrm{p}<0.05)$ compared with all other recycled P sources used in this study in average. In the fluvo-aquic soil, the concentration of Olsen-P in MS and 
CB was not significantly different from CK. However, in red soil, Olsen-P concentration in CB significantly increased by $11.67 \%(\mathrm{p}<0.05)$ compared with CK during the 70 -day incubation. In the fluvo-aquic soil, Olsen $\mathrm{P}$ decreased significantly between day 28 and day 70 after application of superphosphate, while Olsen-P in soils amended with the recycled fertilizers remained stable.

\subsection{All recycled $P$ sources increased moderately labile and sparingly labile soil $P$ fractionations}

Amendment of fluvo-aquic and red soils with different $\mathrm{P}$ sources significantly altered different soil $\mathrm{P}$ fractions and increased the total soil $\mathrm{P}$ content (Table 2, Fig. 2). In both soil types moderately labile and sparingly labile $\mathrm{P}$ fractions accounted for bulk of the P content; however, their relative contribution varied greatly (Fig. 2). In fluvoaquic soil, moderately labile $\mathrm{P}$ was the dominant fraction accounting for $61-67 \%$ of the total $\mathrm{P}$, and the proportion of labile-P, sparingly labile-P and non-labile $\mathrm{P}$ was $7 \%$ to $16 \%, 15 \%$ to $24 \%$ and $7 \%$ to $8 \%$ of total $\mathrm{P}$, respectively (Fig. 2a). In contrast, in red soil, moderately labile $\mathrm{P}$ and sparingly labile $\mathrm{P}$ were present in more or less equal proportion, accounting for $32-39 \%$ and $35-45 \%$ of the total soil $\mathrm{P}$, respectively and the labile-P and non-labile $\mathrm{P}$ accounted for $16-22 \%$ and 6-7 \% of total P, respectively (Fig. 2b).

In fluvo-aquic soil enriched with $\mathrm{SSP}, \mathrm{PM}, \mathrm{CM}$ and $\mathrm{CB}$, the labile $\mathrm{P}$ fraction (Resin-P, $\mathrm{NaHCO}_{3}-\mathrm{Pi}$ and $\mathrm{NaHCO}_{3}-\mathrm{Po}$ ), was increased by $146.07 \%, 94.26 \%, 141.24 \%$ and $27.79 \%$ compared with CK, respectively (Table 1). Similarly, in red soil, SSP, PM and CM addition increased labile P by $50.66 \%, 38.08 \%, 57.93 \%$ and $17.48 \%$ compared with CK, respectively. These results also indicate that among different organic amendments only cattle manure could increase labile soil P fraction similar to that observed with mineral P fertilizer application. Adding different $\mathrm{P}$ sources has increased the moderately labile $\mathrm{P}$ content in the soil, including $\mathrm{NaOH}-\mathrm{Pi}, \mathrm{NaOH}-\mathrm{Po}$ and dil.HCl-P. In fluvo-aquic soils, the moderately labile P fractions of SSP, PM, CM, MS and CB supplemented soils were significantly increased by $2.3 \%, 5.5 \%, 6.8 \%, 1.3 \%$ and $3.5 \%$ compared with $\mathrm{CK}$, respectively. The addition of SSP, PM and MS, but not other sources, in the red soil had a significantly improvement in moderately labile P fraction, by about $7.6 \%, 10.5 \%$ and $13.3 \%$ compared with CK, respectively, after 70 -day incubation. In fluvoaquic soil, both MS and CB significantly increased the concentration of soil sparingly labile fraction (conc.HCl$\mathrm{Pi}+$ conc. $\mathrm{HCl}-\mathrm{Po}$ ). The content of sparingly labile $\mathrm{P}$ in MS and $\mathrm{CB}$ enriched soil was $24.5 \%$ and $44.5 \%$ higher than that in $\mathrm{CK}$, respectively. In red soil supplemented with $\mathrm{CM}, \mathrm{MS}$ and $\mathrm{CB}$, the concentrations of soil sparingly labile $\mathrm{P}$ in treatments were significantly increased by $7.7 \%, 8.4 \%$ and $26.5 \%$ compared with $\mathrm{CK}$, respectively.

In both soils supplemented with SSP, PM and CM, the labile P and the moderately labile P fractions mostly accounted for the increase in Pt content (Fig. 3). In contrast, the increase in Pt in soils enriched with MS and CB mainly came from the moderately stable $\mathrm{P}$ and the inert $\mathrm{P}$ fractions. In the two soils, adding SSP, PM and CM 
significantly increased soil Resin-P and $\mathrm{NaHCO}_{3}-\mathrm{Pi}$ concentrations.

\subsection{Changes in soil organic $P$ species in response to different recycled $P$ sources}

The ${ }^{31} \mathrm{P}-\mathrm{NMR}$ spectra recorded peaks in the $\mathrm{Po}$ and $\mathrm{Pi}$ regions, including monoester $\mathrm{P}$, inorganic orthophosphate, inositol hexakisphosphate, glucose-1-phosphate, DNA P, diester P and Polyphosphates (Fig. 4a, b). In both soils, inorganic orthophosphate was the dominant $\mathrm{P}$ species in $\mathrm{NaOH}$-EDTA extracts. In fluvo-aquic soil, the concentration of inorganic orthophosphate ranged from $38 \mathrm{mg} \cdot \mathrm{kg}^{-1}$ to $110 \mathrm{mg} \cdot \mathrm{kg}^{-1}$ and the peak value of SSP was the highest, followed by CM. In red soil, the concentration of inorganic orthophosphate ranged from 133 $\mathrm{mg} \cdot \mathrm{kg}^{-1}$ to $367 \mathrm{mg} \cdot \mathrm{kg}^{-1}$ and the peak value of CM was the highest, followed by SSP, which was consistent with the soil Olsen-P content and soil active P concentration (Fig. 1 and Table 2). Although the detected signal was weak, compared with SSP, more monoester P and inositol hexakisphosphate signal were detected in PM and CM supplemented both soils (Fig. 4a, b). And more inositol hexakisphosphate was detected of PM supplemented both soils. Compared with fluvo-aquic soil, more inorganic and organic $\mathrm{P}$ forms were detected in red soil.

\subsection{Structural equation modeling (SEM) revealed contrasting effects of soil $\mathrm{pH}$ and total organic carbon} (TOC) on $P$ fraction transformation in fluvo-aquic and red soils enriched with different $P$ sources

The relationship of different attributes of $\mathrm{P}$ sources on its transformation to various $\mathrm{P}$ fractions in fluvo-aquic (Fig. 5a) and red soils (Fig. 5b) were further studied by SEM. SEM explained $95 \%$ and $91 \%$ of Olsen-P variation in fluvo-aquic soil and red soil, respectively. In general, the labile P fractions and the moderately labile P fractions had positive effects on soil Olsen-P of the fluvo-aquic soil and the red soil, while a negative effect was evident with non-labile $\mathrm{P}$ fraction.

TOC and $\mathrm{pH}$ had different effects on various $\mathrm{P}$ fractions in both fluvo-aquic and red soils (Fig. 5). The soil pH turned out to be a major driver of $\mathrm{P}$ transformation. For instance, in the fluvo-aquic soil, $\mathrm{pH}$ had a positive effect on labile $\mathrm{P}$ fraction and moderately labile $\mathrm{P}$ fractions, negative effect on sparingly labile $\mathrm{P}$ fraction and non-labile $\mathrm{P}$ fraction. In the red soil, however, $\mathrm{pH}$ positively influenced both the labile and non-labile $\mathrm{P}$ fraction, while it impacted the moderately labile and sparingly labile P fractions negatively.

In the fluvo-aquic soil, TOC had a negative effect on the labile P fraction and moderate labile $\mathrm{P}$ fraction, but positively influenced the sparingly labile $\mathrm{P}$ and non-labile $\mathrm{P}$ fractions. In the red soil, TOC had a negative effect on labile $\mathrm{P}$ and non-labile $\mathrm{P}$ fractions, while it positively affected moderately labile $\mathrm{P}$ and sparingly labile $\mathrm{P}$ fractions.

\section{Discussion}


In this study, we selected Olsen P as well as the labile and moderately labile fractions of the sequential soil extraction as indicators of bio-available $\mathrm{P}$ level in soil. The effects of different $\mathrm{P}$ sources on soil $\mathrm{P}$ availability decreased in the following order: $\mathrm{SSP}>\mathrm{CM}>\mathrm{PM}>\mathrm{CB} \geq \mathrm{MS}$ (Fig. 1). Mineral $\mathrm{P}$, used here as superphosphate, can be readily dissolved in the soil solution and immediately transformed with less labile soil P fractions or get absorbed by plant roots. In contrast, Po present in manure needs to be mineralized first before entering into the soil solution gradually. It then transforms into less labile P fractions and utilized by crop plants. Therefore, the P availability of both soils amended with superphosphate was higher than that of soil with the recycled fertilizers (Braos et al., 2020).

The results demonstrate that cattle manure had innate advantages over other commonly used renewable $\mathrm{P}$ sources in increasing soil $\mathrm{P}$ availability. In fluvo-aquic soil, the $\mathrm{P}$ availability of soil with mineral P-fertilizer decreased significantly at the end of 70 days' incubation, while the available $\mathrm{P}$ in the soil with recycled $\mathrm{P}$ sources remained flat (Fig. 1). Previous studies have shown that the level of soil available P remains stable following cattle manure application (Mkhonza et al., 2020), but was found decreased when mineral P fertiliser was used (Braos et al., 2020). Some studies suggest that long-term straw retention in the soil improves the content of soil available $P$ (Li et al., 2019; Cao et al., 2021). However, in our study, incorporation of maize straw in the soil did not improve soil P availability in both soils. In long term field studies, the addition of organic matter rather than straw influenced the soil P availability (Huang et al., 2021; Sales et al., 2017). The type of straw and its processing before incorporating into soil may affect its soil enrichment capacity. Thus, future research should consider the management method of straw returning to the field to promote its in situ decomposition and nutrient release to improve soil available $\mathrm{P}$.

The extent of soil $\mathrm{P}$ fraction variation following the application of organic amendments depends to a great extent on the soil type and soil texture (Braos et al., 2020). Compared with fluvo-aquic soil, the P fixation has increased in the red soil with superphosphate, poultry manure and cattle manure amendments (Fig. 1). A comparison of humic acid-treated soils showed higher Olsen-P concentration in the brown and drab soil than that in red soil (Yang. et al., 2013). This is similar to what we observed in our study, indicating an important role for humic acid on $\mathrm{P}$ availability. Further, adding bone meal in the red soil improved soil $\mathrm{P}$ availability, but not in the fluvo-aquic soil. This is because P mainly exists in the form of apatite in bone meal, and the release of P from apatite requires $\mathrm{H}^{+}$(Ylivainio et al., 2008; Jeng and Vagstad, 2009). This suggests that the application of bone meal in red soil will be more valuable. Bone meal is a very important source of available P for crops (Alotaibi et al., 2013; Jeng and Vagstad, 2009), and thus developing methods to recycle P from bone meal will have a remarkable 
impact on alleviating P shortage in the future.

\section{Characterization of soil $\mathbf{P}$ fractions of fluvo-aquic and red soils indicated that cattle manure is a superior soil amendment than other common P sources}

Soil $\mathrm{P}$ fraction analysis found rapid integration of most of the mineral $\mathrm{P}$ into the labile $\mathrm{P}$ fraction (Resin-P, $\mathrm{NaHCO}_{3}-\mathrm{Pi}$ and $\mathrm{NaHCO}_{3}-\mathrm{Po}$ ) (Table 2). Only a small amount of $\mathrm{P}$ was converted into moderately labile $\mathrm{P}$ fractions (NaOH-Pi, NaOH-Po and dil. $\mathrm{HCl}-\mathrm{P}$ ). In the short term, there was no significant effect on the sparingly labile $\mathrm{P}$ (conc. HCl-Pi and conc. HCl-Po) and the residual P fraction (Residual P). However, the concentrations of moderately labile P and sparingly labile P increased in soil with the recycled fertilizers. Correlation analysis showed that there was a significant positive correlation between soil P availability and soil labile P fraction (Fig. S4), and this was further corroborated by the Structural Equation Model analysis (Fig. 5). Soil Resin-P and $\mathrm{NaHCO}_{3}$-Pi fractions were the most effective forms of $\mathrm{P}$ for plant absorption (Negassa and Leinweber, 2010). The provision of $\mathrm{P}$ to soil labile $\mathrm{P}$ fraction differs among different $\mathrm{P}$ sources studied and that became the main reason for the variation in soil available P content in both soils studied. And cattle manure has a significant advantage in improving the availability of soil P over poultry manure, maize straw and cattle bone meal. The percentage of inositol phosphate to total P is about $8 \%$ in cattle manure (Mcdowell et al., 2008; Barnett, 1994), but it is as high as $80 \%$ in poultry manure (Leytem et al., 2008; Yan et al., 2018). Inositol phosphate may complex divalent and trivalent metal elements such as calcium, magnesium, zinc and iron to form extremely insoluble compounds, which can reduce the availability of P (Menezes-Blackburn et al., 2013). This may be an important factor explaining the higher availability of $\mathrm{P}$ in cattle manure-enriched soil than that with poultry manure. In contrast, the other organic amendments, the maize straw and cattle bone meal, are difficult to decompose to increase soil nutrients, including available $\mathrm{P}$, in a short period; hence, the relatively low level of soil labile $\mathrm{P}$ fraction in their $\mathrm{P}$ fractions. Therefore, adding maize straw and cattle bone meal to fluvo-aquic soil will have no significant beneficial effect on soil P availability for some time.

Compared with fluvo-aquic soil, the amount of $\mathrm{NaHCO}_{3}-\mathrm{Po}$ and $\mathrm{NaOH}-\mathrm{Pi}$ in red soil supplemented with superphosphate and poultry manure increased, while that of Resin-P decreased (Fig. 3). P adsorption is mainly controlled by iron (Fe) and aluminum (Al) hydroxides and clay minerals in acid soils (Gerard and Frederic, 2016; Jiang et al., 2012; Gérard, 2016). In neutral and fluvo-aquic soils, the influence of $\mathrm{CaCO}_{3}$ and the precipitation of Ca-phosphates is more important (Pizzeghello et al., 2011). The Fe and $\mathrm{Al}$ ions and hydroxides in red soil increase the sorption and decrease the decomposition of organic $\mathrm{P}$, thereby inhibiting the conversion of moderately labile $\mathrm{P}$ to labile $\mathrm{P}$ fraction (Fan et al., 2019). Therefore, $\mathrm{P}$ is more easily adsorbed and fixed by amorphous $\mathrm{Fe}$ and $\mathrm{Al}$ 
hydroxides in red soil. As a consequence, the accumulation of $\mathrm{P}$ in moderately labile $\mathrm{P}$ fractions in red soil is higher than that in fluvo-aquic soil, which reduces the availability of $\mathrm{P}$ in soil. The change of soil $\mathrm{pH}$ caused by fertilization will affect the adsorption and desorption of $\mathrm{P}$ in soil. In acidic soils, the increase of $\mathrm{pH}$ value and the decrease of extractable aluminum compounds will reduce the adsorption capacity of soil for P (Lopez-Hernandez and Burnham, 1974; Xavier et al., 2009). On the contrary, in fluvo-aquic soil, the precipitation of Ca-phosphates may increase with increasing pH (Adams and Odom, 1985; Gupta et al., 1990). The structural equation model showed that the increase of $\mathrm{pH}$ had a significant positive effect on the labile $\mathrm{P}$ fraction in red soil, while it has no significant effect on the labile P fraction in fluvo-aquic soil (Fig. 5). In our study, the increment of soil Resin-P concentration in red soil after addition of superphosphate was significantly lower than that in fluvo-aquic soil, but there was no significant difference in the increase of soil Resin-P concentration in two soils with cattle manure (Fig.3). This may be due to the increase in soil $\mathrm{pH}$ and the decrease of $\mathrm{P}$ adsorption in the red soil following the addition of cattle manure, and the consequent improvement in soil $\mathrm{P}$ availability.

\section{${ }^{31} \mathrm{P}-\mathrm{NMR}$ analysis of fluvo-aquic and red soil with different $P$ sources}

In this study, a large proportion of orthophosphate was found in soils with large amounts of phosphate mineral fertilizer, which is consistent with other previous reports (Li and Marschner, 2019; Appelhans et al., 2020; Li et al., 2020; Liu et al., 2020a). In addition, orthophosphate in SSP-applied soil was significantly higher than in soil applied with recycled P containing fertilizers (Fig. 4), which was consistent with the soil P availability, indicating that orthophosphate was the main driving factor affecting the $\mathrm{P}$ availability of different $\mathrm{P}$ sources. The addition of poultry manure and cattle manure significantly increased the concentration of monoester $\mathrm{P}$ and inositol hexakisphosphate in both soils. Similarly, the addition of cattle manure and poultry manure increased the content of soil phosphate monoester significantly, but poultry manure had a larger effect than that of cattle manure (Yan et al., 2018; Shafqat et al., 2009). However, the mineralization processes of different organic P components in soil and their mechanism are still unclear. In this regard, studying the microbial processes of $\mathrm{P}$ transformation and their regulation in fluvo-aquic and red soils enriched with different $\mathrm{P}$ sources would provide considerable insights on developing different $\mathrm{P}$ management options for these soil types.

Environmental pollution and resource constraints are global challenges and they also impact $\mathrm{P}$ use efficiency and to improve P use efficiency (Chowdhury et al., 2017). The low P use efficiency in agricultural production system damages ecosystems beyond the acceptable limit and threatens the future food security (Withers, 2019). Optimizing P input, reducing $\mathrm{P}$ loss and recovering $\mathrm{P}$ from biological resources are effective measures to increase the utilization efficiency of P fertilizer (Chadwick et al., 2015). The results of this study indicate that animal manure, 
especially cattle manure, will be a superior renewable $\mathrm{P}$ source with increased bioavailability and is expected to play an important role in managing the limitation of $\mathrm{P}$ resources in agriculture.

\section{Conclusion}

The current study demonstrated that different $\mathrm{P}$ sources had different effects on soil $\mathrm{P}$ availability. They distributed $\mathrm{P}$ differently among different $\mathrm{P}$ fractions. Compared with other recycled phosphate fertilizers, cattle manure was found to be a superior source for improving soil $\mathrm{P}$ availability in fluvo-aquic and red soils. Olsen-P in soil supplemented with cattle manure was increased by $41.16 \%-379.71 \%$ in fluvo-aquic soil and $16.12 \%-70.06 \%$ in red soil compared with those received other recycled P-contained fertilizers. The SEM analysis showed that the soil Olsen-P content was mainly affected by the labile P fraction. ${ }^{31} \mathrm{P}-\mathrm{NMR}$ study showed that amount of orthophosphate was the main factor affecting the availability of $\mathrm{P}$ from different $\mathrm{P}$ sources. In addition, soil $\mathrm{pH}$ and organic matter content have contrasting effect on soil $\mathrm{P}$ transformation process. Better understanding of $\mathrm{P}$ use efficiency of different recycled $\mathrm{P}$ sources and their impact on yield and environmental impact under crop production conditions should be the next logical step.

\section{Author contribution}

Conceptualization: Yuan Wang, Wei Zhang, Torsten Müller, Huaiyu Yang and Xinping Chen; Investigation: Yuan Wang; Writing - Original Draft: Yuan Wang; Visualization: Yuan Wang; ${ }^{31} \mathrm{P}-\mathrm{NMR}$ measurements: Yu Liu; Formal analysis: Yuan Wang and Wei Zhang; Writing - Review \& Editing: Yuan Wang, Wei Zhang, Torsten Müller, Prakash Lakshmanan, Tao Liang, Lin Wang, Huaiyu Yang and Xinping Chen; Funding acquisition: Wei Zhang, Torsten Müller, Huaiyu Yang and Xinping Chen. All authors read and revised the manuscript.

Funding This work was supported by the National Natural Science Foundation of China (No. 32002139), Scientific Research Startup Foundation of Southwest University (SWU019012), the Deutsche Forschungsgemeinschaft (DFG)-328017493/GRK 2366 (Sino-German IRTG AMAIZE-P), the Programme of Introducing Talents of Discipline to Universities (B20053), the National Maize Production System in China (CARS-02-15), and Changjiang Scholarship, Ministry of Education, China.

Acknowledgments The author would like to thank Mr. Guo Shuiquan and Mr. Liu Yongliang for their support and help with soil collection. 


\section{References}

Adams, J. F. and Odom, J. W.: Effects of $\mathrm{pH}$ and phosphorus rates on soil-solution phosphorus and phosphorus availability, Soil Science, 140, 202-205, 1985.

Almeida, R. F., Queiroz, I., Mikhael, J., Oliveira, R. C., and Borges, E. N.: Enriched animal manure as a source of phosphorus in sustainable agriculture, International Journal of Recycling of Organic Waste in Agriculture, 8, 203210, 10.1007/s40093-019-00291-x, 2019.

Alotaibi, K. D., Schoenau, J. J., and Fonstad, T.: Possible utilization of ash from meat and bone meal and dried distillers grains gasification as a phosphorus fertilizer: crop growth response and changes in soil chemical properties, Journal of Soils and Sediments, 13, 1024-1031, 10.1007/s11368-013-0678-2, 2013.

Annaheim, K. E., Doolette, A. L., Smernik, R. J., Mayer, J., Oberson, A., Frossard, E., and Bünemann, E. K.: Long-term addition of organic fertilizers has little effect on soil organic phosphorus as characterized by 31P NMR spectroscopy and enzyme additions, Geoderma, 257-258, 67-77, 10.1016/j.geoderma.2015.01.014, 2015.

Appelhans, S. C., Barbagelata, P. A., Melchiori, R. J. M., Gutierrez Boem, F., and Aitkenhead, M.: Assessing soil $\mathrm{P}$ fractions changes with long-term phosphorus fertilization related to crop yield of soybean and maize, Soil Use and Management, 36, 524-535, 10.1111/sum.12581, 2020.

Barnett, G. M.: Phosphorus forms in animal manure, Bioresource Technology, 49, 139-147, 10.1016/09608524(94)90077-9, 1994.

Borno, M. L., Muller-Stover, D. S., and Liu, F. L.: Contrasting effects of biochar on phosphorus dynamics and bioavailability in different soil types, Science of the Total Environment, 627, 963-974, 10.1016/j.scitotenv.2018.01.283, 2018.

Braos, L. B., Bettiol, A. C. T., Di Santo, L. G., Ferreira, M. E., and Cruz, M. C. P.: Dynamics of phosphorus fractions in soils treated with dairy manure, Soil Research, 58, 289-298, 10.1071/Sr18325, 2020.

Cade-Menun, B. and Liu, C. W.: Solution Phosphorus-31 Nuclear Magnetic Resonance spectroscopy of soils from 2005 to 2013: A review of sample preparation and experimental parameters, Soil Science Society of America Journal, 78, 19-37, 10.2136/sssaj2013.05.0187dgs 2014.

Cade-Menun, B. J.: Characterizing phosphorus in environmental and agricultural samples by $31 \mathrm{P}$ nuclear magnetic resonance spectroscopy, Talanta, 66, 359-371, 10.1016/j.talanta.2004.12.024, 2005.

Campbell, B. M., Beare, D. J., Bennett, E. M., Hall-Spencer, J. M., Ingram, J. S. I., Jaramillo, F., Ortiz, R., Ramankutty, N., Sayer, J. A., and Shindell, D.: Agriculture production as a major driver of the Earth system exceeding planetary boundaries, Ecology and Society, 22, 8, 10.5751/es-09595-220408, 2017.

Cao, D., Lan, Y., Sun, Q., Yang, X., Chen, W., Meng, J., Wang, D., and Li, N.: Maize straw and its biochar affect phosphorus distribution in soil aggregates and are beneficial for improving phosphorus availability along the soil profile, European Journal of Soil Science, 1-15, 10.1111/ejss.13095, 2021.

Chadwick, D., Jia, W., Tong, Y. a., Yu, G., Shen, Q., and Chen, Q.: Improving manure nutrient management towards sustainable agricultural intensification in China, Agriculture Ecosystems \& Environment, 209, 34-46, 10.1016/j.agee.2015.03.025, 2015.

Chen, G. L., Xiao, L., Xia, Q. L., Wang, Y., Yuan, J. H., Chen, H., Wang, S. Q., and Zhu, Y. Y.: Characterization of different phosphorus forms in flooded and upland paddy soils incubated with various manures, ACS Omega, 6 , 3259-3266, 10.1021/acsomega.0c05748, 2021.

Chowdhury, R. B., Moore, G. A., Weatherley, A. J., and Arora, M.: Key sustainability challenges for the global phosphorus resource, their implications for global food security, and options for mitigation, Journal of Cleaner Production, 140, 945-963, 10.1016/j.jclepro.2016.07.012, 2017.

Cui, M., Guo, Q., Wei, R., and Tian, L.: Human-driven spatiotemporal distribution of phosphorus flux in the environment of a mega river basin, Science of the Total Environment, 752, 141781, 
10.1016/j.scitotenv.2020.141781, 2021.

Ding, S., Di, X. U., Bin, L. I., Fan, C., and Zhang, C.: Improvement of (31)P NMR spectral resolution by 8 hydroxyquinoline precipitation of paramagnetic $\mathrm{Fe}$ and $\mathrm{Mn}$ in environmental samples, Environmental Science and Technology, 44, 2555-2561, 10.1021/es903558g, 2010.

Fan, Y., Zhong, X., Lin, F., Liu, C., Yang, L., Wang, M., Chen, G., Chen, Y., and Yang, Y.: Responses of soil phosphorus fractions after nitrogen addition in a subtropical forest ecosystem: Insights from decreased $\mathrm{Fe}$ and $\mathrm{Al}$ oxides and increased plant roots, Geoderma, 337, 246-255, 10.1016/j.geoderma.2018.09.028, 2019.

Freiberg, Y., Fine, P., Levkovitch, I., and Baram, S.: Effects of the origins and stabilization of biosolids and biowastes on their phosphorous composition and extractability, Waste Management, 113, 145-153, 10.1016/j.wasman.2020.06.002, 2020.

Garcia-Albacete, M., Martin, A., and Cartagena, M. C.: Fractionation of phosphorus biowastes: Characterisation and environmental risk, Waste Management, 32, 1061-1068, 10.1016/j.wasman.2012.02.003, 2012.

Gatiboni, L. C., Schmitt, D. E., Cassol, P. C., Comin, J. J., Heidemann, J. C., Brunetto, G., and Nicoloso, R. D.: Samples disturbance overestimates phosphorus adsorption capacity in soils under long-term application of pig slurry, Archives of Agronomy and Soil Science, 65, 1262-1272, 10.1080/03650340.2018.1562274, 2019.

Gerard and Frederic: Clay minerals, iron/aluminum oxides, and their contribution to phosphate sorption in soils A myth revisited, Geoderma, 262, 213-226, 10.1016/j.geoderma.2015.08.036, 2016.

Gérard, F.: Clay minerals, iron/aluminum oxides, and their contribution to phosphate sorption in soils - A myth revisited, Geoderma, 2016.

Guan, X. K., Wei, L., Turner, N. C., Ma, S. C., Yang, M. D., and Wang, T. C.: Improved straw management practices promote in situ straw decomposition and nutrient release, and increase crop production, Journal of Cleaner Production, 250, 1-13, 10.1016/j.jclepro.2019.119514, 2020.

Gupta, R. K., Singh, R. R., and Tanji, K. K.: Phosphorus release in sodium ion dominated soils, Soil Science Society of America Journal, 54, 1254-1260, 10.2136/sssaj1990.03615995005400050009x, 1990.

Haslam, R., Darch, T., and Blackwell, M.: Phosphorus use efficiency and fertilizers: future opportunities for improvements, Frontiers of Agricultural Science and Engineering, 6, 10.15302/j-fase-2019274, 2019.

Hill, J. E. and Cade-Menun, B. J.: Phosphorus-31 nuclear magnetic resonance spectroscopy transect study of poultry operations on the Delmarva Peninsula, Journal of Environmental Quality, 38, 130, 10.2134/jeq2007.0587, 2009.

Huang, W., Jian-Fu, W. U., Pan, X. H., Tan, X. M., and Zeng, Y. H.: Effects of long-term straw return on soil organic carbon fractions and enzyme activities in a double-cropped rice paddy in South China, Journal of Integrative Agriculture, 20, 236-247, 10.1016/S2095-3119(20)63347-0, 2021.

Jeng, A. S. and Vagstad, N.: Potential nitrogen and phosphorus leaching from soils fertilized with meat and bone meal, Acta Agriculturae Scandinavica, Section B - Plant Soil Science, 59, 238-245, 10.1080/09064710802024164, 2009.

Jiang, Wang, RK, and Yang: Adsorption of chromate on variable charge soils as influenced by ionic strength, Environmental Earth Sciences, 2012,66(4), 1155-1162, 2012.

Joshi, S. R., Li, W., Bowden, M., and Jaisi, D. P.: Sources and pathways of formation of recalcitrant and residual phosphorus in an agricultural soil, Soil Systems, 2, 10.3390/soilsystems2030045, 2018.

Kaikake, K., Sekito, T., and Dote, Y.: Phosphate recovery from phosphorus-rich solution obtained from chicken manure incineration ash, Waste Management, 29, 1084-1088, 10.1016/j.wasman.2008.09.008, 2009.

Kalkhajeh, Y. K., Huang, B., Sorensen, H., Holm, P. E., and Hansen, H. C. B.: Phosphorus accumulation and leaching risk of greenhouse vegetable soils in Southeast China, Pedosphere, 31, 683-693, 10.1016/s10020160(21)60029-2, 2021. 
Lemming, C., Nielsen, M. T. S., Jensen, L. S., Scheutz, C., and Magid, J.: Phosphorus availability of sewage sludges and ashes in soils of contrasting pH, Journal of Plant Nutrition and Soil Science, 183, 682-694, 10.1002/jpln.201900323, 2020.

Leytem, A. B., Widyaratne, G. P., and Thacker, P. A.: Phosphorus utilization and characterization of ileal digesta and excreta from broiler chickens fed diets varying in cereal grain, phosphorus level, and phytase addition, Poultry Science, 87, 2466-2476, 10.3382/ps.2008-00043, 2008.

Li, F. Y., Liang, X. Q., Zhang, H. F., and Tian, G. M.: The influence of no-till coupled with straw return on soil phosphorus speciation in a two-year rice-fallow practice, Soil and Tillage Research, 195, 10.1016/j.still.2019.104389, 2019.

Li, G., Li, H., Leffelaar, P. A., Shen, J., and Zhang, F.: Characterization of phosphorus in animal manures collected from three (dairy, swine, and broiler) farms in China, PLoS One, 9, e102698, 10.1371/journal.pone.0102698, 2014. Li, J. and Marschner, P.: Phosphorus Pools and Plant Uptake in Manure-Amended Soil, Journal of Soil Science and Plant Nutrition, 19, 175-186, 10.1007/s42729-019-00025-y, 2019.

Li, M., Mazzei, P., Cozzolino, V., Monda, H., Hu, Z., and Piccolo, A.: Optimized procedure for the determination of $\mathrm{P}$ species in soil by liquid-state 31P-NMR spectroscopy, Chemical and Biological Technologies in Agriculture, 2, 10.1186/s40538-014-0027-8, 2015.

Li, M., Cozzolino, V., Mazzei, P., Drosos, M., Monda, H., Hu, Z., and Piccolo, A.: Effects of microbial bioeffectors and $\mathrm{P}$ amendements on $\mathrm{P}$ forms in a maize cropped soil as evaluated by 31P-NMR spectroscopy, Plant and Soil, 10.1007/s11104-017-3405-8, 2017.

Li, X., Wen, Q.-X., Zhang, S.-Y., Li, N., Yang, J.-F., and Han, X.: Long-term rotation fertilisation has differential effects on soil phosphorus, Plant, Soil and Environment, 66, 543-551, 10.17221/263/2020-pse, 2020.

Liang, X., Jin, Y., He, M., Liu, Y., Hua, G., Wang, S., and Tian, G.: Composition of phosphorus species and phosphatase activities in a paddy soil treated with manure at varying rates, Agriculture Ecosystems \& Environment, 237, 173-180, 10.1016/j.agee.2016.12.033, 2017.

Lin, H., Gan, J., Rajendran, A., Reis, C. E. R., and Hu, B.: Phosphorus removal and recovery from digestate after biogas production, in: Biofuels - Status and Perspective, 517-546, 10.5772/60474, 2015.

Liu, J., Han, C., Zhao, Y., Yang, J., Cade-Menun, B. J., Hu, Y., Li, J., Liu, H., Sui, P., Chen, Y., and Ma, Y.: The chemical nature of soil phosphorus in response to long-term fertilization practices: Implications for sustainable phosphorus management, Journal of Cleaner Production, 272, 10.1016/j.jclepro.2020.123093, 2020a.

Liu, X., Yuan, Z., Liu, X., Zhang, Y., and Jiang, S.: Historic trends and future prospects of waste generation and recycling in china's phosphorus cycle, Environmental Science and Technology, 54, 5131-5139, 10.1021/acs.est.9b05120, 2020b.

Liu, X., Sheng, H., Jiang, S., Yuan, Z., Zhang, C., and Elser, J. J.: Intensification of phosphorus cycling in China since the 1600s, Proceedings of the National Academy of Sciences of the United States of America, 113, 26092614, 10.1073/pnas.1519554113, 2016.

Lopez-Hernandez, D. and Burnham, C. P.: The effect of pH on phosphate adsorption in soils Journal of Soil Science, 35, 283-297, 10.1111/j.1365-2389.1984.tb00283.x, 1974.

Lu, X. C., Mahdi, A. K., Han, X. Z., Chen, X., Yan, J., Biswas, A., and Zou, W. X.: Long-term application of fertilizer and manures affect $P$ fractions in Mollisol, Scientific Reports, 10, 10.1038/s41598-020-71448-2, 2020.

Lucas, E. R., Toor, G. S., and McGrath, J. M.: Agronomic and environmental phosphorus decline in coastal plain soils after cessation of manure application, Agriculture Ecosystems \& Environment, 311, 10.1016/j.agee.2021.107337, 2021.

McDowell, R. W., Dou, Z., Toth, J. D., Cade-Menun, B. J., Kleinman, P. J., Soder, K., and Saporito, L.: A comparison of phosphorus speciation and potential bioavailability in feed and feces of different dairy herds using 
$31 \mathrm{p}$ nuclear magnetic resonance spectroscopy, Journal of Environmental Quality, 37, 741-752, 10.2134/jeq2007.0086, 2008.

McLaren, T. I., Smernik, R. J., McLaughlin, M. J., Doolette, A. L., Richardson, A. E., and Frossard, E.: The chemical nature of soil organic phosphorus: A critical review and global compilation of quantitative data, in, Advances in Agronomy, 51-124, 10.1016/bs.agron.2019.10.001, 2020.

Menezes-Blackburn, D., Jorquera, M. A., Greiner, R., Gianfreda, L., and Mora, M. D.: Phytases and phytase-labile organic phosphorus in manures and soils, Critical Reviews in Environmental Science and Technology, 43, 916954, 10.1080/10643389.2011.627019, 2013.

Mkhonza, N. P., Buthelezi-Dube, N. N., and Muchaonyerwa, P.: Phosphorus availability and fractions in a humic soil amended with poultry manure and lime, South African Journal of Plant and Soil, 37, 361-366, 10.1080/02571862.2020.1797196, 2020.

Mortola, N., Romaniuk, R., Cosentino, V., Eiza, M., Carfagno, P., Rizzo, P., Bres, P., Riera, N., Roba, M., Butti, M., Sainz, D., and Brutti, L.: Potential Use of a Poultry Manure Digestate as a Biofertiliser:Evaluation of Soil Properties and Lactuca sativa Growth, Pedosphere, 29, 60-69, 10.1016/s1002-0160(18)60057-8, 2019.

Negassa, W. and Leinweber, P.: How does the Hedley sequential phosphorus fractionation reflect impacts of land use and management on soil phosphorus: A review, Journal of Plant Nutrition and Soil Science, 172, 305-325, 10.1002/jpln.200800223, 2009.

Negassa, W. and Leinweber, P.: How does the Hedley sequential phosphorus fractionation reflect impacts of land use and management on soil phosphorus: A review, Journal of Plant Nutrition and Soil Science, 172, 305-325, 10.1002/jpln.200800223, 2010.

Neufeld, K. R., Grayston, S. J., Bittman, S., Krzic, M., Hunt, D. E., and Smukler, S. M.: Long-term alternative dairy manure management approaches enhance microbial biomass and activity in perennial forage grass, Biology and Fertility of Soils, 53, 613-626, 10.1007/s00374-017-1204-2, 2017.

Olsen, S. R.: Estimation of available phosphorus in soils by extraction with sodium bicarbonate, Miscellaneous Paper Institute for Agricultural Research Samaru Pp, 1954.

Pagliari, P. H. and Laboski, C. A. M.: Dairy manure treatment effects on manure phosphorus fractionation and changes in soil test phosphorus, Biology and Fertility of Soils, 49, 987-999, 10.1007/s00374-013-0798-2, 2013.

Pizzeghello, D., Berti, A., Nardi, S., and Morari, F.: Phosphorus forms and P-sorption properties in three alkaline soils after long-term mineral and manure applications in north-eastern Italy, Agriculture Ecosystems \& Environment, 141, 58-66, 10.1016/j.agee.2011.02.011, 2011.

Powers, S. M., Chowdhury, R. B., Macdonald, G. K., Metson, G. S., Beusen, A., Bouwman, A. F., Hampton, S. E., Mayer, B. K., Mccrackin, M. L., and Vaccari, D. A.: Global opportunities to increase agricultural independence through phosphorus recycling, Earth's Future, 370-383, 10.1029/2018EF001097, 2019.

Qaswar, M., Chai, R. S., Ahmed, W., Jing, H., Han, T. F., Liu, K. L., Ye, X. X., Xu, Y. M., Anthonio, C. K., and Zhang, H. M.: Partial substitution of chemical fertilizers with organic amendments increased rice yield by changing phosphorus fractions and improving phosphatase activities in fluvo-aquic soil, Journal of Soils and Sediments, 20, 1285-1296, 10.1007/s11368-019-02476-3, 2020.

Sales, M., Aleixo, S., Gama-Rodrigues, A. C., and Gama-Rodrigues, E. F.: Structural equation modeling for the estimation of interconnections between the $\mathrm{P}$ cycle and soil properties, Nutrient Cycling in Agroecosystems, 10.1007/s10705-017-9879-1, 2017.

Schumacher, B. A.: Methods for the determination of total organic carbon (TOC) in soils and sediments, 1-5, 2002. Shafqat, M. N., Pierzynski, G. M., and Xia, K.: Phosphorus source effects on soil organic phosphorus: A P-31 NMR study, Communications in Soil Science and Plant Analysis, 40, 1722-1746, 10.1080/00103620902895821, 2009. 
Shen, Z. Q., Zhang, Q., Liu, L. J., and Qiu, Y.: Determination of available phosphorus in soil by sodium bicarbonate extraction Mo-Sb anti-spectrophotometry method, Environmental Monitoring and Forewarning, 2011. Tiessen and Moir: Characterization of available P by sequential extraction, CRC Press1993.

Tiessen, H., Stewart, J. W. B., and Cole, C. V.: Pathways of phosphorus transformations in soils of differing pedogenesis, Soil Science, 43, 583-588, 10.2136/sssaj1984.03615995004800040031x, 1984.

Turner, B. L.: Soil organic phosphorus in tropical forests: an assessment of the NaOH-EDTA extraction procedure for quantitative analysis by solution 31P NMR spectroscopy, European Journal of Soil Science, 59, 453-466, 10.1111/j.1365-2389.2007.00994.x, 2008.

Wang, L. M., Amelung, W., Prietzel, J., and Willbold, S.: Transformation of organic phosphorus compounds during 1500 years of organic soil formation in Bavarian Alpine forests - A P-31 NMR study, Geoderma, 340, 192-205, 10.1016/j.geoderma.2019.01.029, 2019.

Withers, P. J. A.: Closing the phosphorus cycle, Nature Sustainability, 2, 1001-1002, 10.1038/s41893-019-0428-6, 2019.

Xavier, F. A. D. S., Oliveira, T. S. D., Andrade, F. V., and Mendona, E. d. S.: Phosphorus fractionation in a sandy soil under organic agriculture in Northeastern Brazil, Geofisica Internacional, 151, 417-423, 10.1016/j.geoderma.2009.05.007, 2009.

Xu, D., Ding, S., Li, B., Jia, F., Xiang, H., and Zhang, C.: Characterization and optimization of the preparation procedure for solution P-31 NMR analysis of organic phosphorus in sediments, Journal of Soils \& Sediments, 12, 909-920, 2012.

Yan, Z., Chen, S., Dari, B., Sihi, D., and Chen, Q.: Phosphorus transformation response to soil properties changes induced by manure application in a calcareous soil, Geoderma, 322, 163-171, 10.1016/j.geoderma.2018.02.035, 2018.

Yang., K., Guan, L., Zhu, J., and Li, Y.: Effects of exogenous humic acids on forms of organic phosphorus in three contrasting types of soil, Communications in Soil Science \& Plant Analysis, 44, 2095-2106, 10.1080/00103624.2013.799679, 2013.

Ylivainio, K., Uusitalo, R., and Turtola, E.: Meat bone meal and fox manure as P sources for ryegrass (Lolium multiflorum) grown on a limed soil, Nutrient Cycling in Agroecosystems, 81, 267-278, 10.1007/s10705-007-9162y, 2008.

Yuan, J., Wang, L., Chen, H., Chen, G., and Wang, Y.: Responses of soil phosphorus pools accompanied with carbon composition and microorganism changes to phosphorus-input reduction in paddy soils, Pedosphere, 31 , 83-93, 10.1016/S1002-0160(20)60049-2, 2021.

Zaccheo, P., Genevini, P., and Ambrosini, D.: The role of manure in the management of phosphorus resources at an Italian crop-livestock production farm, Agriculture Ecosystems \& Environment, 66, 231-239, 10.1016/s01678809(97)00106-0, 1997.

Zhang, F., Zhang, K., Li, G., Zhang, W., Zhang, T., Hou, Y., Ma, L., Yuan, L., Zhang, J., Feng, G., Zhang, L., Meng, F., Jiao, X., Wang, L., and Shen, J.: Innovations of phosphorus sustainability: implications for the whole chain, Frontiers of Agricultural Science and Engineering, 6, 10.15302/j-fase-2019283, 2019.

Zhang, W., Zhang, Y., An, Y., and Chen, X.: Phosphorus fractionation related to environmental risks resulting from intensive vegetable cropping and fertilization in a subtropical region, Environmental Pollution, 269, 116098, 10.1016/j.envpol.2020.116098, 2021.

Zhang, Y. Q., Bhattacharyya, R., Dalal, R. C., Wang, P., Menzies, N. W., and Kopittke, P. M.: Impact of land use change and soil type on total phosphorus and its fractions in soil aggregates, Land Degradation \& Development, 31, 828-841, 10.1002/1dr.3501, 2020.

Zhang, Y. T., Hao, X. Y., Alexander, T. W., Thomas, B., Shi, X. J., and Lupwayi, N. Z.: Long-term and legacy 
https://doi.org/10.5194/soil-2021-127

Preprint. Discussion started: 10 November 2021

(C) Author(s) 2021. CC BY 4.0 License.

Sol EG

585 effects of manure application on soil microbial community composition, Biology and Fertility of Soils, 54, 269-

$586 \quad 283,10.1007 / \mathrm{s} 00374-017-1257-2,2018$.

587

588

589 
https://doi.org/10.5194/soil-2021-127

Preprint. Discussion started: 10 November 2021

(c) Author(s) 2021. CC BY 4.0 License.

SOIL

Discussions

Table 1 The specific amount of fertilizer for different treatments.

\begin{tabular}{ccccc}
\hline Treatments & $\begin{array}{c}\text { Recycled fertilizers } \\
\left(\mathrm{g} \cdot \mathrm{kg}^{-1}\right)\end{array}$ & $\begin{array}{c}\mathrm{Ca}\left(\mathrm{H}_{2} \mathrm{PO}_{4}\right)_{2} \\
\left(\mathrm{~g} \cdot \mathrm{kg}^{-1}\right)\end{array}$ & $\begin{array}{c}\mathrm{Ca}\left(\mathrm{NO}_{3}\right)_{2} \cdot 4 \mathrm{H}_{2} \mathrm{O} \\
\left(\mathrm{g} \cdot \mathrm{kg}^{-1}\right)\end{array}$ & $\begin{array}{c}\mathrm{KCl} \\
\left(\mathrm{g} \cdot \mathrm{kg}^{-1}\right)\end{array}$ \\
\hline CK & 0.00 & 0.00 & 1.69 & 0.62 \\
SSP & 0.00 & 0.45 & 1.69 & 0.62 \\
PM & 5.93 & 0.00 & 0.89 & 0.25 \\
CM & 26.55 & 0.00 & 0.18 & 0.01 \\
MS & 22.06 & 0.00 & 0.40 & 0.30 \\
CB & 0.65 & 0.00 & 1.29 & 0.62 \\
\hline
\end{tabular}

Note: SSP: $\mathrm{Ca}\left(\mathrm{H}_{2} \mathrm{PO}_{4}\right)_{2}$; PM: Poultry Manure; CM: Cattle Manure; MS: Maize Straw; CB: Cattle Bone Meal. 


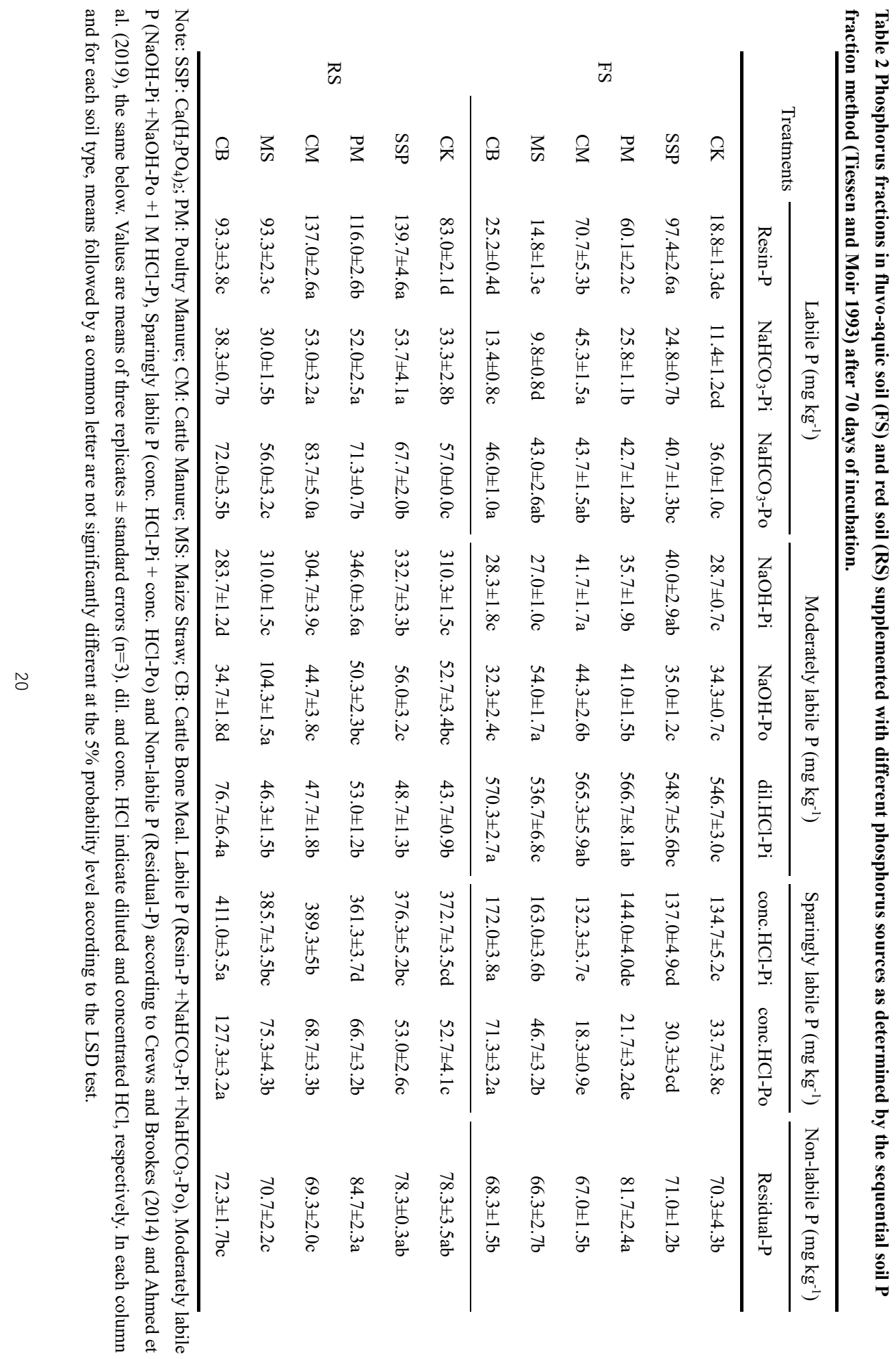




\section{Figure Captions}

Figure 1 Changes in Olsen-P concentrations in fluvo-aquic soil (a) and red soil (b) supplemented with different phosphorus sources during 70-day incubation. Values are means $\pm \mathrm{SE}(\mathrm{n}=4)$. SSP: $\mathrm{Ca}\left(\mathrm{H}_{2} \mathrm{PO}_{4}\right)_{2}$; PM: Poultry Manure; CM: Cattle Manure; MS: Maize Straw; CB: Cattle Bone Meal. The same below.

Figure 2 The proportion of different soil P fractions in fluvo-aquic soil (a) and red soil (b) supplemented with different phosphorus sources after 70-day incubation. Orange, green, purple, and grey indicate labile P, moderately labile $\mathrm{P}$, sparingly labile $\mathrm{P}$, and non-labile $\mathrm{P}$, respectively.

Figure 3 Changes in P fractions in fluvo-aquic soil (a) and red soil (b) supplemented with different phosphorus sources after 70-day incubation (the values presented are those measured with addition of different phosphorus sources minus the value of no phosphorus fertilizer control).

Figure 4 Liquid ${ }^{31} \mathrm{P}$ NMR spectra of NaOH-EDTA extracts of a fluvo-aquic soil (a) and a red soil (b) amended with different $\mathrm{P}$-containing fertilizers. In the upper spectrum, the shift positions of the different $\mathrm{P}$ compounds are indicated. A: Monoester P (7.19 to $7.58 \mathrm{ppm})$; B: Inorganic orthophosphate (6.18 to $6.34 \mathrm{ppm})$; C: Inositol hexakisphosphate (4.38 to 4.49 ppm); D: Glucose-1-phosphate (3.13 to $3.43 \mathrm{ppm})$; E: DNA P (-0.15 to -0.36 ppm); F: Diester P (-1.73, -2.43 ppm); G: Polyphosphates (-4.63 to -5.83 ppm). Concentrations of $\mathrm{P}$ compounds in NaOHEDTA extracts of fluvo-aquic soil (c) and red soil (d) by ${ }^{31} \mathrm{P}-\mathrm{NMR}$.

Figure 5 Structural equation model (SEM) analysis for the transformation of different $\mathrm{P}$ fractions after the addition of different P-containing fertilizers in a fluvo-aquic soil (a) and a red soil (b). Optimal model fitting results under the fluvo-aquic soil (a): $\chi^{2}=0.098, \mathrm{DF}=1, \chi^{2} / \mathrm{DF}=0.098, \mathrm{P}=0.754$, and $\mathrm{RMSEA}=0.000$; optimal model fitting results under the red soil (b): $\chi^{2}=0.241, \mathrm{DF}=1, \chi^{2} / \mathrm{DF}=0.241, \mathrm{P}=0.623$, and RMSEA $=0.000$. The number on the arrow represents the standardized path coefficient, the red and blue arrows represent the positive and negative effects, respectively. *,** and $* * *$ indicate significant at $\mathrm{P}<0.05, \mathrm{P}<0.01$ and $\mathrm{P}<0.001$, respectively. The black number above each variable is $\mathrm{R}^{2}$ values, which represent the proportion of variance explained for each variable. The arrow width indicates the strength of the paths. Soil $\mathrm{pH}$ and total organic carbon (TOC) data are shown in Supplementary Figure S3 

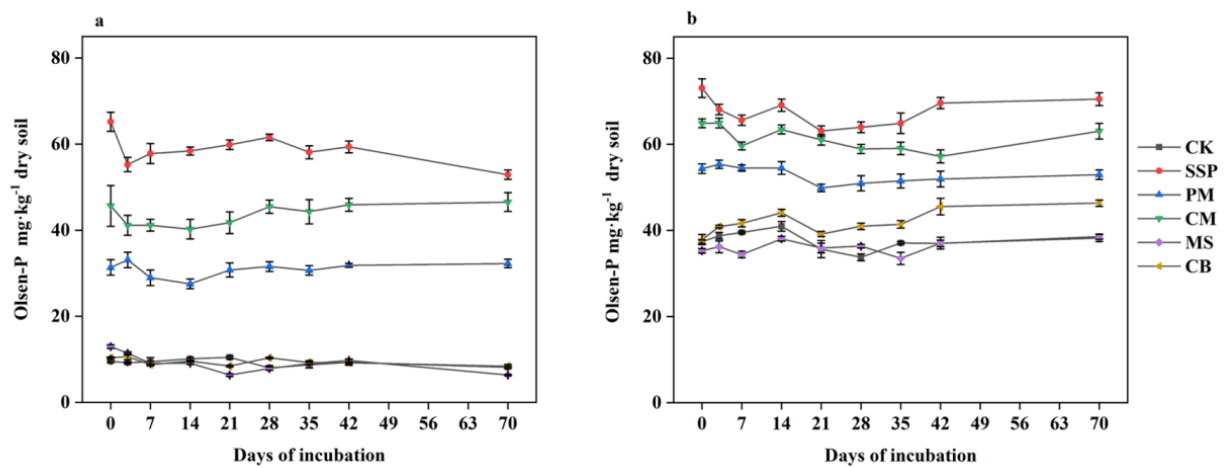
https://doi.org/10.5194/soil-2021-127

Preprint. Discussion started: 10 November 2021

(c) Author(s) 2021. CC BY 4.0 License.

son EĞ
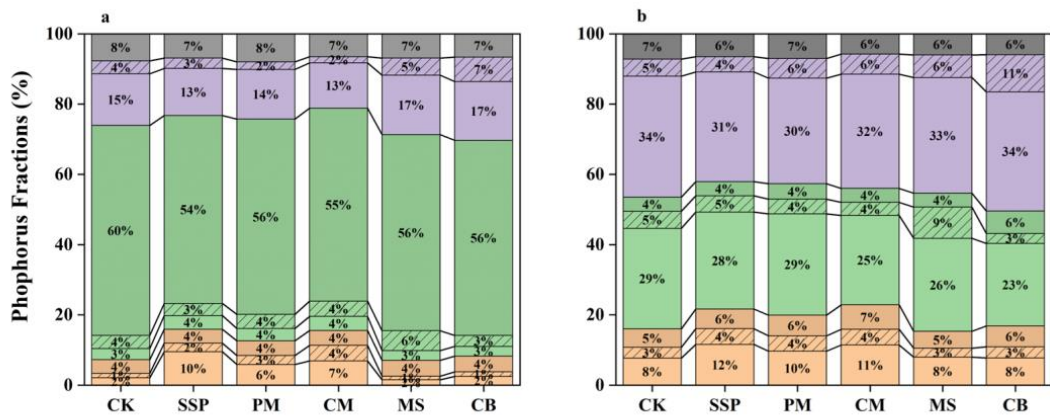
https://doi.org/10.5194/soil-2021-127

Preprint. Discussion started: 10 November 2021

(c) Author(s) 2021. CC BY 4.0 License.

son EĞ
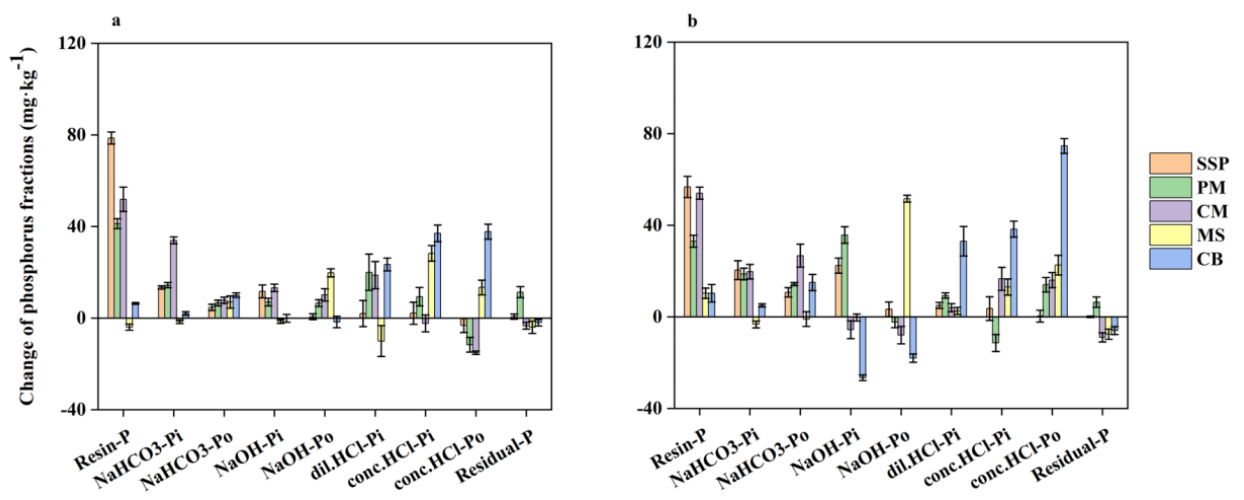
a
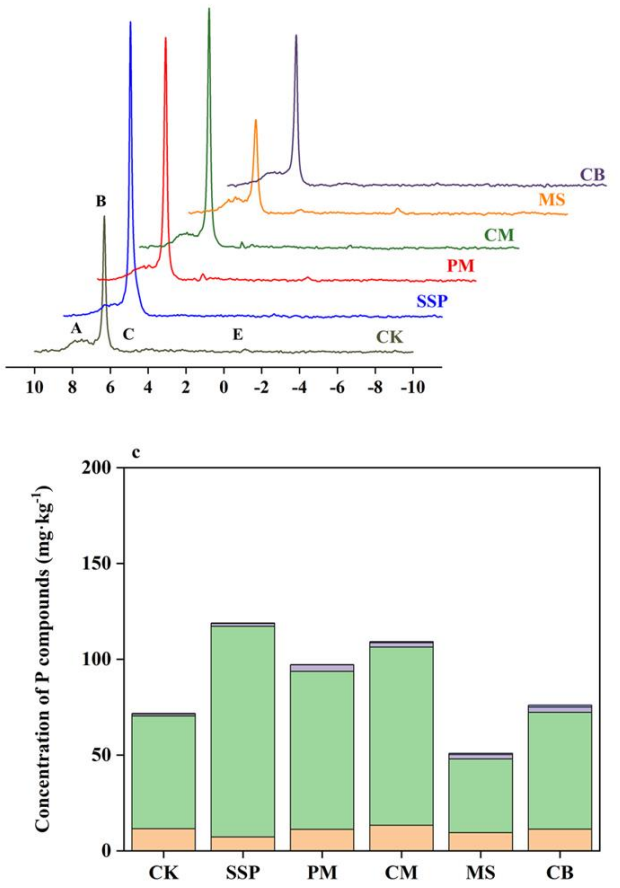
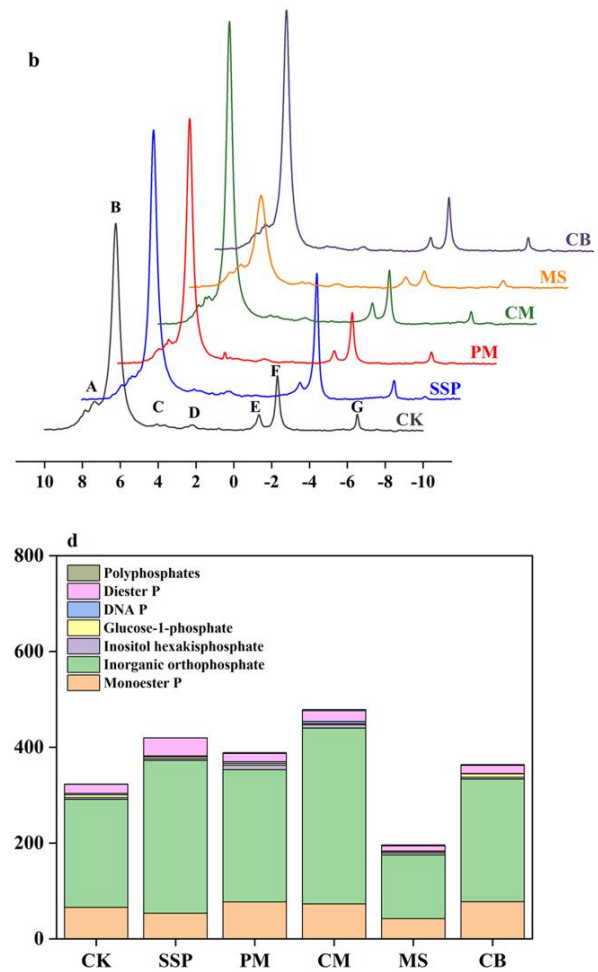
https://doi.org/10.5194/soil-2021-127

Preprint. Discussion started: 10 November 2021

(C) Author(s) 2021. CC BY 4.0 License.

(c) (1)

636

Figure 5
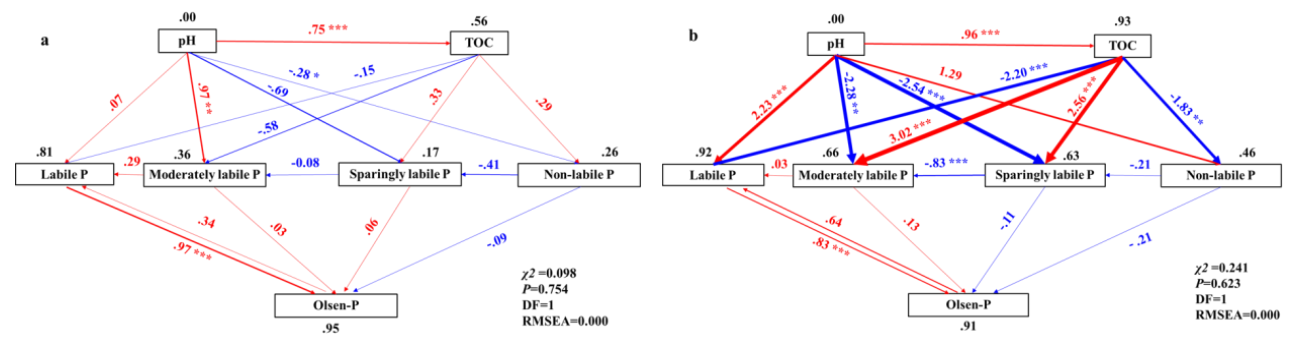